\title{
Case Report: Case report: Mixed infection of Plasmodium vivax and Plasmodium falciparum in a tertiary hospital [version 1;
} peer review: 2 approved]

\author{
Abeer M. Al-Subaie \\ Dammam, Saudi Arabia
}

Department of Clinical Laboratory Sciences, College of Applied Medical Sciences, Imam AbdulRahman Bin Faisal University,
Abstract

Mixed infections with two or more species of Plasmodium are frequently reported due to vector factors, parasite factors (formation of hypnozoites) and host factors (residing in endemic areas, travel to endemic areas, inadequately treated previous infection, lack of compliance to therapy). Here we report a case of a 33-year-old Saudi female who had a significant travel history, and a peripheral blood smear (PBS) revealed mixed infection with $P$. falciparum and $P$. vivax. The case was successfully treated with a combination therapy of artemisinin and primaquine with follow up testing at three, seven, 14, and 28 days.

Mixed malaria infections are especially reported in travelers to endemic areas. Hence, adequate diagnosis and appropriate treatment of the cases contributes majorly to preventing relapse and controlling the disease. Travel consultations should be given to all travelers before their trips to endemic countries.

\section{Keywords}

Malaria, Falciparum malaria, Plasmodium vivax, Plasmodium

falciparum, case report

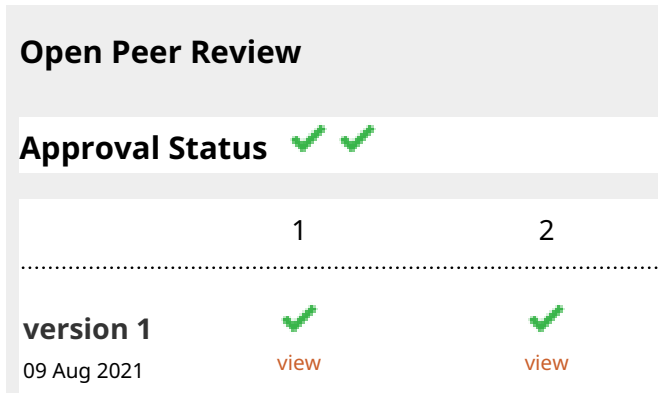

Corresponding author: Abeer M. Al-Subaie (amnalsubaie@iau.edu.sa)

Author roles: Al-Subaie AM: Conceptualization, Data Curation, Formal Analysis, Methodology, Writing - Original Draft Preparation, Writing - Review \& Editing

Competing interests: No competing interests were disclosed.

Grant information: The author(s) declared that no grants were involved in supporting this work.

Copyright: (c) 2021 Al-Subaie AM. This is an open access article distributed under the terms of the Creative Commons Attribution License, which permits unrestricted use, distribution, and reproduction in any medium, provided the original work is properly cited.

How to cite this article: Al-Subaie AM. Case Report: Case report: Mixed infection of Plasmodium vivax and Plasmodium falciparum in a tertiary hospital [version 1; peer review: 2 approved] F1000Research 2021, 10:779 https://doi.org/10.12688/f1000research.53162.1 First published: 09 Aug 2021, 10:779 https://doi.org/10.12688/f1000research.53162.1 


\section{Introduction}

Malaria is a vector-borne disease caused by protozoan parasites belonging to genus Plasmodium, and is considered to be one of the most important parasitic infections throughout the world, resulting in high mortality rates ${ }^{1}$. There were previously four known species responsible for human malaria: $P$. falciparum, $P$. vivax, $P$. ovale, $P$. malariae. Recently, it was discovered that there is also a fifth species, known as $P$. knowlesi ${ }^{2}$. $P$. falciparum and $P$. vivax have the widest distribution, while $P$. malariae has a very low prevalence ${ }^{3}$.

The Kingdom of Saudi Arabia (KSA) has reported 61 and 38 indigenous malaria cases in the years 2018 and 2019 respectively (World Health Organization (WHO), World Malaria Report 2020). The indigenous cases in KSA have decreased drastically over the years (272 cases in 2016 to 38 in 2019) due to the implementation of the National Malaria Control Program (NMCP), the establishment of mobile units with specific focus on undocumented migrants from neighboring countries where diagnosis, treatment and medical care are provided free of charge to all imported $\operatorname{cases}^{4}(\mathrm{WHO}, 2020)$.

The majority of malaria infection cases in KSA are due to $P$. falciparum (97\%) followed by $P$. vivax (2\%). P. falciparum causes malignant tertian malaria occasionally associated with severe complications in infected individuals. Another concern with $P$. falciparum infection is recrudescence, resulting in treatment failure and emergence of antimalarial drug resistance to chloroquine (WHO, 2020).

\section{Case report}

A 33-year-old Saudi female, Eastern region resident was admitted to the 'Infectious Diseases' ward of our teaching hospital King Fahad Hospital of the University, Imam AbdulRahman bin Faisal University with 'fever of other and unknown origin'. The patient presented with a seven-day fever with chills and complained of decreased appetite and generalized body pain associated with dark urine, pale stool and diarrhea, with history of fever with chills and generalized body pains for one week. On taking detailed history, the patient stated that she had recently returned from a 20-day trip to the Ivory Coast. The patient didn't have any form of comorbidities and denied any history of animal contact, immunocompromised status, or intake of any kind of prescribed or illicit drugs or raw milk ingestion during this period. Family history of the patient revealed absence of hereditary blood diseases and was of insignificant relation to the patient's clinical presentation. The patient did not seek any medical facility prior her admission to our hospital and has only self-administrated paracetamol tablets in response to the fever and body aches.

On recording the vital signs (measurement of body temperature, weight, blood pressure and pulse rate), the patient was febrile with an oral temperature of $39.9^{\circ} \mathrm{C}$, tachycardic with a pulse rate of 118 beats/minute, blood pressure of $135 / 85 \mathrm{mmHg}$, and respiratory rate of 20 breaths/minute.

Upon physical examination, the patient appeared ill and had pale conjunctivae. Lymphadenopathy was noted in the left axillary $(1 \times 1 \mathrm{~cm}$ and $0.5 \times 1.5 \mathrm{~cm})$ and left inguinal region $(0.5 \times 2 \mathrm{~cm})$. Skin appeared normal and there were no petechiae. The results of hematological testing revealed the patient had normocytic normochromic anemia, pancytopenia (Table 1), and liver function test (LFT) were borderline with significantly high levels of lactate dehydrogenase indicating an active haemolysis (Table 2). The peripheral blood smear (PBS) depicted $P$. falciparum gametocytes (crescent) and $P$. vivax gametocytes (of ameboid shape with Schüffner's dots). PBS was then repeated on three, seven, 14, and 28 days. C-reactive protein (CRP) plasma level and erythrocyte sedimentation rate (ESR), which are both inflammatory blood markers that indicate an ongoing infection, were higher than the normal levels (Table 3). Serological testing included measuring the antibody levels (both their Immunoglobulin (Ig) $\mathrm{IgG}$ and $\mathrm{IgM}$ forms) for Epstein-Barr virus (EBV), and Cytomegalovirus (CMV). The patient's results were positive for both EBV IgG and CMV IgG (Table 4). It is worth mentioning that there were no challenges encountered either in clinically examining the patient or getting access to the laboratory diagnostic tests.

The patient was treated as follows: oral doxycycline $100 \mathrm{mg}$ once a day, artesunate $200 \mathrm{mg}$ orally once a day for three days, and sulfadoxine and pyrimethamine $1500 \mathrm{mg}+75 \mathrm{mg}$ single dose orally on day one. On the third day, after excluding

Table 1. Complete blood count (CBC), differential white blood cells (WBCs) count and coagulation tests.

\begin{tabular}{|c|c|c|}
\hline Test & $\begin{array}{l}\text { Patient } \\
\text { result }\end{array}$ & $\begin{array}{l}\text { Reference } \\
\text { interval }\end{array}$ \\
\hline Hemoglobin & $7.6 \mathrm{~g} / \mathrm{dL}$ & $12-16 \mathrm{~g} / \mathrm{dL}$ \\
\hline Hematocrit & $22.8 \%$ & $37-47 \%$ \\
\hline Red blood cells & $2.65 \times 10^{12} / L$ & $4.2-5.5 \times 10^{12} / \mathrm{L}$ \\
\hline MCV & $85.9 \mathrm{fL}$ & 80-94 fL \\
\hline $\mathrm{MCH}$ & $28.5 \mathrm{pg}$ & $27-32 \mathrm{pg}$ \\
\hline WBCs & $3.2 \times 10^{9} / \mathrm{L}$ & $4-11 \times 10^{9} / L$ \\
\hline \multicolumn{3}{|l|}{ Differential WBCs count } \\
\hline Neutrophils & $41.7 \%$ & $40-75 \%$ \\
\hline Lymphocytes & $44.6 \%$ & $20-45 \%$ \\
\hline Monocytes & $11.9 \%$ & $3-9 \%$ \\
\hline Eosinocytes & $1.3 \%$ & $0-6 \%$ \\
\hline Basophils & $0.5 \%$ & $0-1 \%$ \\
\hline Platelets & $120 \times 10^{9} / L$ & $140-450 \times 10^{9} / \mathrm{L}$ \\
\hline \multicolumn{3}{|l|}{ Coagulation tests } \\
\hline Prothrombin time & 13.8 seconds & $10-14$ seconds \\
\hline Partial thromboplastin time & 29 seconds & $30-45$ seconds \\
\hline $\begin{array}{l}\text { International Normalized } \\
\text { Ratio }\end{array}$ & 1.3 ISI & 1-2 ISI \\
\hline
\end{tabular}


Table 2. Biochemistry and liver function tests.

\begin{tabular}{|l|l|l|}
\hline Test & $\begin{array}{l}\text { Patient } \\
\text { result }\end{array}$ & $\begin{array}{l}\text { Reference } \\
\text { interval }\end{array}$ \\
\hline Total Protein & $7.5 \mathrm{~g} / \mathrm{dL}$ & $6.4-8.2 \mathrm{~g} / \mathrm{dL}$ \\
\hline Albumin & $3.0 \mathrm{~g} / \mathrm{dL}$ & $3.4-5.0 \mathrm{~g} / \mathrm{dL}$ \\
\hline Sodium & $136 \mathrm{mEq} / \mathrm{L}$ & $136-145 \mathrm{mEq} / \mathrm{L}$ \\
\hline Potassium & $4.0 \mathrm{mEq} / \mathrm{L}$ & $3.5-5.1 \mathrm{mEq} / \mathrm{L}$ \\
\hline Blood urea nitrogen & $6 \mathrm{mg} / \mathrm{dL}$ & $7-18 \mathrm{mg} / \mathrm{dL}$ \\
\hline Creatinine & $0.68 \mathrm{mg} / \mathrm{dL}$ & $0.6-1.0 \mathrm{mg} / \mathrm{dL}$ \\
\hline Lactate dehydrogenase & $589 \mathrm{U} / \mathrm{L}$ & $81-234 \mathrm{U} / \mathrm{L}$ \\
\hline Total Bilirubin & $0.7 \mathrm{mg} / \mathrm{dL}$ & $0.2-1.0 \mathrm{mg} / \mathrm{dL}$ \\
\hline Direct Bilirubin & $0.19 \mathrm{mg} / \mathrm{dL}$ & $0.05-0.2 \mathrm{mg} / \mathrm{dL}$ \\
\hline Alkaline phosphatase & $135 \mathrm{U} / \mathrm{L}$ & $46-116 \mathrm{U} / \mathrm{L}$ \\
\hline $\begin{array}{l}\text { Gamma-glutamyl } \\
\text { transferase }\end{array}$ & $235-55 \mathrm{U} / \mathrm{L}$ & $5-55 \mathrm{U} / \mathrm{L}$ \\
\hline $\begin{array}{l}\text { Aspartate } \\
\text { aminotransferase }\end{array}$ & $28 \mathrm{U} / \mathrm{L}$ & $15-37 \mathrm{U} / \mathrm{L}$ \\
\hline Alanine transaminase & $30 \mathrm{U} / \mathrm{L}$ & $14-36 \mathrm{U} / \mathrm{L}$ \\
\hline & & \\
\hline
\end{tabular}

Table 3. Inflammatory blood markers tests.

\begin{tabular}{|l|l|l|}
\hline Test & $\begin{array}{l}\text { Patient } \\
\text { result }\end{array}$ & $\begin{array}{l}\text { Reference } \\
\text { interval }\end{array}$ \\
\hline $\begin{array}{l}\text { C-reactive protein } \\
\text { quantitative test }\end{array}$ & $7.00 \mathrm{mg} / \mathrm{dl}$ & $0.05-0.3 \mathrm{mg} / \mathrm{dl}$ \\
\hline $\begin{array}{l}\text { Erythrocyte } \\
\text { sedimentation rate }\end{array}$ & $>50 \mathrm{~mm} /$ hour & $0-20 \mathrm{~mm} / \mathrm{hour}$ \\
\hline
\end{tabular}

Table 4. Virology screening tests.

\begin{tabular}{|l|l|}
\hline Test & Patient result \\
\hline $\begin{array}{c}\text { Epstein-Bar virus (EBV) IgG } \\
\text { IgM }\end{array}$ & $\begin{array}{l}\text { Positive } \\
\text { Negative }\end{array}$ \\
\hline $\begin{aligned} \text { Cytomegalovirus (CMV) IgG } \\
\text { IgM }\end{aligned}$ & $\begin{array}{l}\text { Positive } \\
\text { Equivocal }\end{array}$ \\
\hline
\end{tabular}

glucose-6-phophate dehydrogenase (G6PD) deficiency by measuring the G6PD enzyme level, oral primaquine $30 \mathrm{mg} /$ day for three days was added to the treatment regimen. After seven days of the treatment, the patient's symptoms had resolved; the PBS was repeated and revealed the absence of morphological forms of both parasites along with normal CBC and LFT results. Treatment and care provided to the patient was free of any financial charges. During the treatment course the patient did not develop any adverse effects due to the administrated medications. Figure 1 summarizes the timeline of the case management course.

\section{Discussion}

Several studies conducted worldwide and in KSA report that malaria mixed infections are not uncommon ${ }^{5-8}$. The majority of malaria studies in KSA were studies conducted in the Southwest area and included cases of mixed P.falciparum and P.vivax infections ${ }^{9-11}$. However, in the Eastern province of KSA where this case is reported, there have been few cases of single or mixed infection malaria reported due to effective control measures which resulted in the termination of malaria transmission ${ }^{11}$.

Mixed infections in malaria can be attributed to one or more of four reasons: several species of Anopheles can carry more than one species of the parasite; P.vivax can remain as hypnozoites in the liver, which can be cause a relapse; recrudescence in P.falciparum infection due to drug resistant forms; and incomplete treatment of a previous infection ${ }^{12}$.

Microscopic examination of PBS for the morphological forms of the malarial parasite remains the gold standard for laboratory confirmation of the infection ${ }^{11}$. However, making a diagnosis of malaria mixed infection based on a PBS microscopic diagnosis is challenging. This difficulty can be due to: low levels of parasitemia; altered morphology of the parasite due to self-treatment; or the similarity in Plasmodium species, e.g. P. knowlesi is often misdiagnosed as $P$. malariae or P. falciparum $^{12}$.

Several tests can be used in conjunction with the PBS such as rapid diagnostic tests (RDT), antibody detection using indirect fluorescent antibody tests (IFA), and polymerase chain reaction (PCR) to identify the infection. However, all these methods have their own limitations. The RDT cannot detect low level parasitemia while IFA is time consuming, subjective, requires fluorescence microscopy and a trained observer ${ }^{13}$. However, molecular tests such as PCR can assist in definitive species determination and also can detect low level parasitemia (about one parasite/ $\mu \mathrm{L}$ of blood) (Centers for Disease Control and Prevention $)^{13}$. It was not possible to perform a PCR test in the time this patient was diagnosed in our hospital due to the unavailability of the test in our laboratory, which was a limitation in the diagnostic approach.

The main strategy in treatment of uncomplicated malaria consists of oral therapy with a combination of two agents, the artemisinin and a partner drug that eliminates the remaining parasites, (in the case of chloroquine resistance) or chloroquine monotherapy (in the case of chloroquine sensitivity) (WHO, 2020). Treatment for chloroquine-resistant $P$. falciparum should be administered in the setting of known exposure to a chloroquine-resistant region, unknown prevalence of chloroquine resistance, or uncertain exposure history. As a result, artemisinin-based combination therapies (ACT) have become the first line of treatment for $P$. falciparum and mixed malaria infections. The 


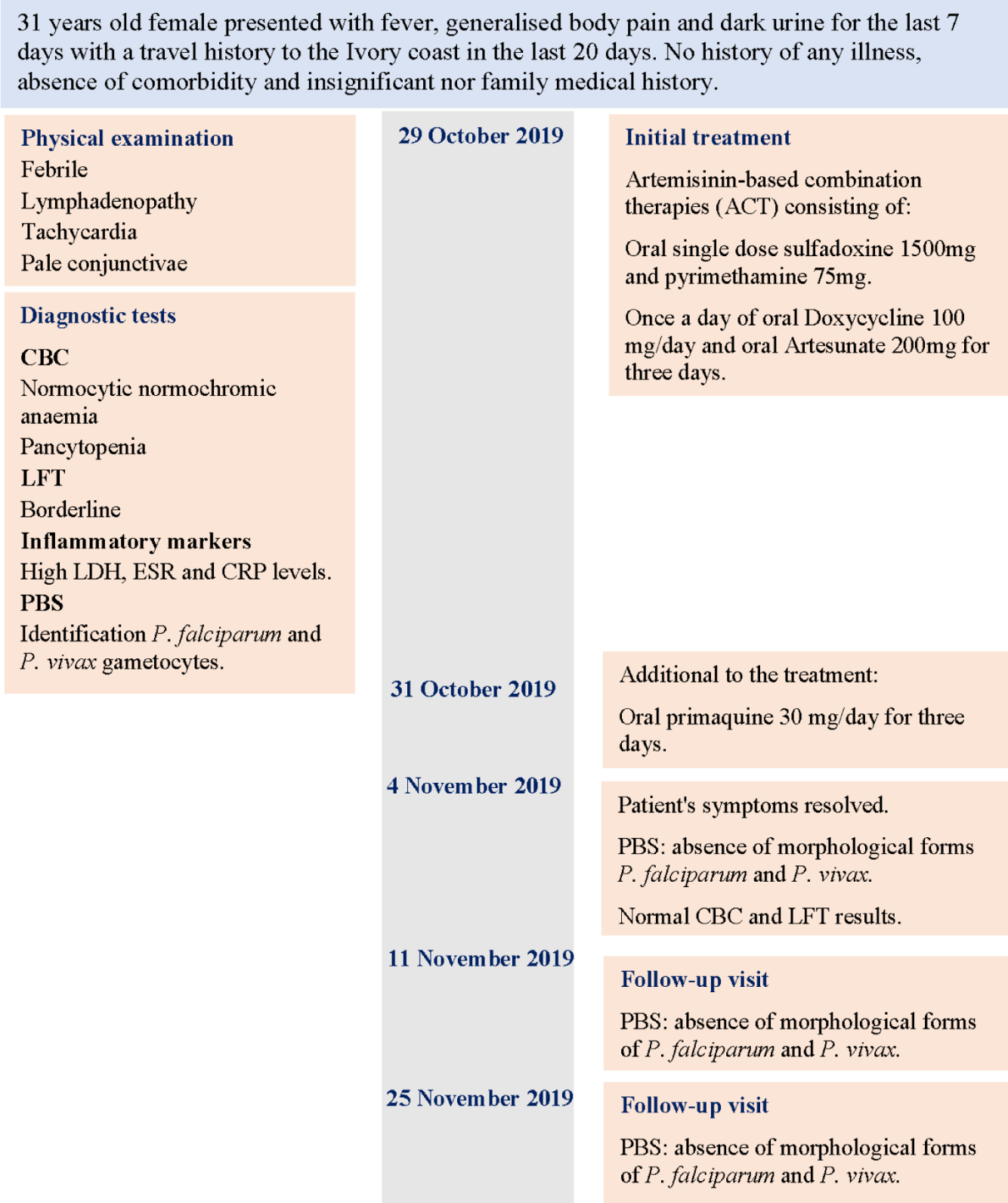

\section{Clearance of the mixed malaria infection and its clinical manifestation.}

Figure 1. Case management timeline of $\boldsymbol{P}$. falciparum and $\boldsymbol{P}$. vivax mixed infection. CBC Complete blood count; LFT Liver function test; LDH Lactate Dehydrogenase; ESR Erythrocyte sedimentation rate; CRP C-reactive protein; PBS Peripheral blood smear.

ACT regimens have few side effects and are cidal to all the asexual stages of the parasite in the blood, causing rapid clearance of the infection ${ }^{14}$.

In this reported case, the patient received an ACT regimen comprising artesunate, sulfadoxine and pyrimethamine. Doxycycline was also chosen as it has high patient compliance and can be given once daily, and the seven-day course of these tablets finishes after the ACT regimen. Primaquine is given in malarial mixed infections along with ACT as it is the only drug recommended to eliminate the intrahepatic forms (hypnozoites) of $P$. vivax and gametocytes of $P$. falciparum. However, the patient's G6PD levels should be tested to prevent primaquine-induced hemolysis as a phenolic metabolite, 
5-hydroxyprimaquine (5-HPQ), mediates primaquine hemotoxicity by generating reactive oxygen species (ROS) within erythrocytes that overwhelm antioxidant defenses ${ }^{15,16}$. Supportive care should be given to the patient to prevent morbidity and mortality. In addition, inappropriate combinations and inadequate dosing of drugs should be avoided to prevent drug resistance and relapse (WHO, 2021). As there is no available malarial vaccine, chemoprophylaxis can be administered to travelers before visiting the endemic areas according to (WHO, 2021).

Overall, this reported case has one limitation at the diagnostic level: the unavailability of the quantitative real-time PCR (q-PCR) test to confirm the identification of both the malaria species and to measure the level of the parasitemia, since q-PCR is more reliable in detecting mixed infection at levels of low parasitemia'. Although it would have been an added value in terms of confirmation, q-PCR unavailability did not affect the proper diagnosis. The accuracy in the PBS examination enabled the identification of both malaria species which is considered one of the strengths of this case. Another strength of this reported case is the timely, appropriate management plan. The patient responded well with the treatment without any side effects and the parasitemia was resolved in due time.

To conclude, malarial infection can be controlled with different measures taken at different levels: appropriate vector control measures; early case detection; timely management; entomological monitoring; population movement monitoring and surveillance; reporting of cases; and public health education strategies.

\section{Data availability}

All data underlying the results are available as part of the article and no additional source data are required.

\section{Consent}

Written informed consent for publication of patient's clinical details was obtained from the patient.
1. Kamareddine $\mathrm{L}$ : The biological control of the malaria vector. Toxins (Basel). 2012; 4(9): 748-767.

PubMed Abstract | Publisher Full Text | Free Full Text

2. Antinori S, Galimberti L, Milazzo L, et al.: Biology of human malaria plasmodia including Plasmodium knowlesi. Mediterr J Hematol Infect Dis. 2012; 4(1): e2012013.

PubMed Abstract | Publisher Full Text | Free Full Text

3. Ashley EA, Phyo AP, Woodrow CJ: Malaria. Lancet. 2018; 391(10130): 1608-1621. PubMed Abstract | Publisher Full Text

4. Al Zahrani MH, Omar AI, Abdoon AMO, et al:: Cross-border movement economic development and malaria elimination in the Kingdom of Saudi Arabia. BMC Med. 2018; 16(1): 98.

PubMed Abstract | Publisher Full Text | Free Full Text

5. Genton B, D'Acremont $\mathrm{V}$, Rare $\mathrm{L}$, et al.: Plasmodium vivax and mixed infections are associated with severe malaria in children: a prospective cohort study from Papua New Guinea. PLoS Med. 2008; 5(6): e127. PubMed Abstract | Publisher Full Text | Free Full Text

6. Khan W, Zakai HA, Umm-E-Asma: Clinico-pathological studies of Plasmodium falciparum and Plasmodium vivax - malaria in India and Saudi Arabia. Acta Parasitol. 2014: 59(2): 206-12.

PubMed Abstract | Publisher Full Text

7. Amer OS, Waly MI, Burhan IW, et al.: Epidemiological trends of malaria in the Western regions of Saudi Arabia: a cross sectional study. J Infect Dev Ctries. 2020; 14(11): 1332-1337.

PubMed Abstract | Publisher Full Text

8. Darraj MA: Clinical Profile of Severe Plasmodium falciparum and P. vivax Malaria in Jazan Region, Saudi Arabia. Mal J Med Health Sci. 2020; 16(4): 73-80. Reference Source

9. Bin Dajem SM: Molecular investigation of mixed malaria infections in
Southwest Saudi Arabia. Saudi Med J. 2015; 36(2): 248-51 PubMed Abstract | Publisher Full Text | Free Full Text

10. Hawash $Y$, Ismail $K$, Alsharif $K$, et al.: Malaria Prevalence in a Low Transmission Area, Jazan District of Southwestern Saudi Arabia. Korean J Parasitol. 2019; 57(3): 233-242. PubMed Abstract | Free Full Text

11. Soliman RH, Garcia-Aranda P, Elzagawy SM, et al.: Imported and autochthonous malaria in West Saudi Arabia: results from a reference hospital. Malar J. 2018; 17(1): 286

PubMed Abstract | Publisher Full Text | Free Full Text

12. Fontenille $\mathrm{D}$, Lepers JP, Coluzzi M, et al.: Malaria transmission and vector biology on Sainte Marie Island, Madagascar. J Med Entomol. 1992; 29(2): 197-202.

PubMed Abstract | Publisher Full Text

13. Talapko J, Škrlec I, Alebić T, et al:: Malaria: The Past and the Present. Microorganisms. 2019; 7(6): pii: E179. PubMed Abstract | Publisher Full Text | Free Full Text

14. Newton $\mathrm{P}$, White $\mathrm{N}$ : Malaria: new developments in treatment and prevention. Annu Rev Med. 1999; 50: 179-92. PubMed Abstract | Publisher Full Text

15. Recht J, Ashley EA, White NJ: Use of primaquine and glucose-6-phosphate dehydrogenase deficiency testing: Divergent policies and practices in malaria endemic countries. PLoS Negl Trop Dis. 2018; 12(4): e0006230. PubMed Abstract | Publisher Full Text | Free Full Text

16. Bowman ZS, Morrow JD, Jollow DJ, et al.: Primaquine-induced hemolytic anemia: role of membrane lipid peroxidation and cytoskeletal protein alterations in the hemotoxicity of 5-hydroxyprimaquine. J Pharmacol Exp Ther. 2005; 314(2): 838-45. PubMed Abstract | Publisher Full Text 


\title{
Open Peer Review
}

\section{Current Peer Review Status:}

\section{Version 1}

Reviewer Report 21 September 2021

https://doi.org/10.5256/f1000research.56516.r92549

(C) 2021 Gabali A. This is an open access peer review report distributed under the terms of the Creative Commons Attribution License, which permits unrestricted use, distribution, and reproduction in any medium, provided the original work is properly cited.

\begin{abstract}
Ali M. Gabali
Department of Pathology, Karmanos Cancer Center, Wayne State University School of Medicine, Detroit, MI, USA

'The paper reviewed presented a Mixed infection of Plasmodium vivax and Plasmodium falciparum in a tertiary hospital. The authors discussed thoroughly the clinical presentation of concomitant Plasmodium vivax and falciparum infection in this case and the clinical course and modality of therapy used. The case is addressing an important issue; the presentation and clinical course are largely well explained and appropriately used and the paper is well written. My conclusion is to approve the paper for indexing.
\end{abstract}

Is the background of the case's history and progression described in sufficient detail? Yes

Are enough details provided of any physical examination and diagnostic tests, treatment given and outcomes?

Yes

Is sufficient discussion included of the importance of the findings and their relevance to future understanding of disease processes, diagnosis or treatment? Yes

Is the case presented with sufficient detail to be useful for other practitioners? Yes

Competing Interests: No competing interests were disclosed.

Reviewer Expertise: Immunology, hematology and hematopathology

I confirm that I have read this submission and believe that I have an appropriate level of 
expertise to confirm that it is of an acceptable scientific standard.

Reviewer Report 01 September 2021

https://doi.org/10.5256/f1000research.56516.r91522

(C) $2021 \mathrm{El}$ Chaar M. This is an open access peer review report distributed under the terms of the Creative Commons Attribution License, which permits unrestricted use, distribution, and reproduction in any medium, provided the original work is properly cited.

\section{Mira El Chaar}

Faculty of Health Sciences, University of Balamand, Beirut, Lebanon

The case study presented by the authors is well elaborated. The authors describe in detail the sequence of the clinical outcome of a patient who was admitted to the hospital with plasmodium species coinfections.

The Sequence of the case is well presented including the background, the method of detection, the result, and the discussion.

The authors have tackled the limitation of this study in particular the absence of real-time PCR to study the parasitaemia level in the patient which is very important.

The article needs minor changes for indexing including the following:

1. All laboratory tests and markers could be presented in one table instead of 4 tables. If the authors prefer to keep it as such, table 4 should be deleted.

2. The authors should mention the year when the patient was admitted to the hospital in the result part, although it is included in figure 1.

3. It is worth mentioning in the discussion about the prevalence of coinfection of plasmodium species at the regional and international levels.

4. The authors should mention in the discussion if coinfection can increase the severity of the disease.

Is the background of the case's history and progression described in sufficient detail? Yes

Are enough details provided of any physical examination and diagnostic tests, treatment given and outcomes?

Yes

Is sufficient discussion included of the importance of the findings and their relevance to future understanding of disease processes, diagnosis or treatment?

Yes 
Is the case presented with sufficient detail to be useful for other practitioners?

Yes

Competing Interests: No competing interests were disclosed.

I confirm that I have read this submission and believe that I have an appropriate level of expertise to confirm that it is of an acceptable scientific standard.

The benefits of publishing with F1000Research:

- Your article is published within days, with no editorial bias

- You can publish traditional articles, null/negative results, case reports, data notes and more

- The peer review process is transparent and collaborative

- Your article is indexed in PubMed after passing peer review

- Dedicated customer support at every stage

For pre-submission enquiries, contact research@f1000.com 